\title{
An Evaluation of Inventory Management Practices Impact on Return on Asset: A Study on Beverage, Food and Tobacco Sector Listed Companies of Sri Lanka
}

\author{
V.Sritharan ${ }^{1 *} \quad$ S.Sivalingam ${ }^{2}$ \\ 1. Department of Accounting university of Jaffna, Jaffna, Sri Lanka \\ 2. Faculty of graduate studies, university of kelaniya, kelaniya, Sri Lanka
}

\begin{abstract}
Inventory is a vital part of current assets mainly in manufacturing and business concerns. Huge funds are committed to inventories as to ensure smooth flow of production and to meet consumer demand. Inventory management plays a crucial role in balancing the benefits and cost associated with holding inventory. Effective and efficient inventory management goes a long way in survival of a business firm. Inventory management practices effects on return on asset of the companies in beverage food and tobacco sector in Sri Lanka Colombo stock exchange at a great scope. A panel data from 2012 to 2016 was gathered for the analysis from the annual reports of 20 beverage food and tobacco sector firms considered. The multiple regression model was applied in the data analysis to find out the relationship between inventory management practices and return on asset. The variables used include inventory conversion period, operating cycle, current ratio, cash conversion cycle and return on assets. The results provide a significant positive relationship between inventory conversion periods and return on asset. In addition to that, cash conversion cycle was found significant negative relationship with the profitability measures of return on asset.
\end{abstract}

Keywords: Inventory Management; Beverage Food and Tobacco sector; Return on asset

DOI: $10.7176 /$ RJFA/11-14-02

Publication date:July $31^{\text {st }} 2020$

\section{Introduction}

Inventory plays a significant role in the growth and survival of all organizations. Managing assets of all kinds can be viewed as an inventory problem; the principles used in inventories can also be applied to cash and fixed assets too. Usually, the literature of inventory focuses on production and procurement as the principal determinants of corporate inventory policy and management. In this sense, the trade-off between ordering costs and holding costs characterizes the transactions approach to inventory management represented by the Classic ( $\mathrm{s}, \mathrm{S}$ ) policy model and Economic Order Quantity (EOQ) models of inventory developed many decades ago. In recent years, as the field of operations management has developed, many new concepts have been added to the list of relevant inventory control topics (Koumanakos, D 2008), The Effect of Inventory Management on Firm Performance).

The just-in-time (JIT), material requirements planning systems (MRP) and enterprise resource planning (ERP) methods while another emerging stream of studies postulates that the characteristics of a firm's demand and marketing environments also play an important role in determining optimal corporate inventories and these are more management-oriented. Notwithstanding the theoretical or practical shortcomings inherent in these concepts and techniques, their application in real business life should have an effect in firms' performance (Koh et al., 2007).

Building on this intuition, our purpose of this study is to explore the impact (if any) of inventory management on Sri Lankan Beverage Food and Tobacco company's profitability. Inventory conversion period (ICP), current ratio (CR) operating cycle (OC) and cash conversion cycle (CCC) serve as our proxy for the implementation of inventory management whereas Return on Asset was used as the profitability of beverage food and tobacco Companies of Sri Lanka.

Most literature texts declare that cost minimization or profit maximization is the main criteria for optimal inventory management, for example, an inventory manager's goal is modeled at minimizing cost or maximizing profit while satisfying customers' demands. The combined impact of demand planning, inventory optimization, and profit maximization can result in huge savings through reduced inventory in the system, lower clearance costs and better financial efficiencies. However, it is a large effort and it impacts a large number of users in an enterprise.

Too much inventory consumes physical space, creates a financial burden, and increases the possibility of damage, spoilage and loss. Furthermore, excessive inventory frequently compensates for inefficient and sloppy management, haphazard scheduling, poor forecasting, and inadequate attention to the process and procedures. Conversely, too little inventory often disrupts business operations, and increases the probability of poor customer service. In many cases good customers may become furious and take their business somewhere else if the desired product or service is not immediately available.

In the operations management literature, the question of how much inventory a firm should keep has been extensively studied even though there is dichotomy in the views given that inventory is both an asset and a liability. 
In the empirical evidence of the inventory management-performance relationship also produced mixed results. Specifically, Milgrom and Roberts (1988) and Dudley and Lasserre (1989) indicated that timely and informative customer demand data can result in improved profitability through reduced inventories. Deloof (2003) documents a significant negative relation between gross operating income and the number of inventories days for a sample of non-financial Belgian firms during the period 1992-1996, suggesting that managers can create value for their shareholders by reducing the number of inventories days to a reasonable minimum. Huson and Nanda (1995) proved that the improvement of inventory turnover (following JIT adoption) by a sample of 55 firms led to an increase in earnings per share. Additional evidence from Belgium is provided by Boute et al. (2004), who found no overall decrease of inventory ratios despite any increased focus on inventory reduction and Boute et al. (2006), who concluded that companies with very high inventory ratios have more possibilities to be bad financial performers. This is consistent with the findings of Shin and Soenen (1998), which reported a strong negative relation between the cash conversion cycle and corporate profitability for a large sample of public American firms.

Chen et al. (2005) in their views of inventories policies, reported that firms with abnormally high inventories have abnormally poor stock returns, firms with abnormally low inventories have ordinary stock returns while firms with slightly lower than average inventories perform best over time. Furthermore, in a other study of Shah and Shin (2007) examined the empirical associations among three constructs - inventory, IT investments and financial performance - using longitudinal data that span four decades, where they conclude that reducing inventories has a significant and direct relationship with financial performance.

Contrary to the findings of the aforementioned studies, Balakrishnan et al. (1996), with the use of a small sample size though (46 firms), reported that the accounting performance of JIT adopters declines slightly compared to a matched sample of non-adopters. Further, Rotemberg and Saloner (1989) reported that a commonly identified positive association between corporate inventories and sales is greater for more concentrated industries.

Given that the results from the above few empirical studies on the microeconomic determinants and consequences of inventories are somewhat contradictory, so our study will try to shed more light to tests this issue with recent sample of Sri Lankan Beverage Food and Tobacco Companies.

The use of Sri Lankan evidence may lead to an assessment of the general applicability of inferences drawn from relevant research in different countries. To sort out the independent effects of inventories management in firms' profitability we initially utilized a linear regression model estimated by this representative sector and for each of the years 2011 to $2015(2011 / 2012$ to $2015 / 2016)$.

\section{Problem Statement}

Many of the organizations fail to scrutinize their investment in inventory is found in the quest to maximize return on investment (Sitienei and Memba, 2016). This is unfortunate because improving the way an organization controls and manages inventory may have the greatest potential for improving the organization's bottom line (Schreibfeder, 2004). According to Temeng et al (2010), if the inventory properly managed, organizations can make potential savings but most of the organizations have continuously ignored it. For this purpose inventory should be treated as a necessary asset and requiring management.

Beverage Food and Tobacco is an essential sector to Sri Lanka and plays an important role in terms of its substantial contribution towards the growth in Gross Domestic Product (GDP) of the country (LKR 258,862 million in 2014 and annual growth rate for 2018first quarter is $+06.4 \%$ ), which is necessary for the country's socioeconomic growth and development. In the year of 2014, Beverage Food and Tobacco sector also was as the most performing sector in market. Recently, there has been a growing demand of Beverage food and Tobacco from hotels and tourism development activities. The government's industrial policy is to encourage investment in Food and Beverages industries as Sri Lanka has a comparative advantage. The Board of Investment (BOI) offers various incentives for investors. Also, Research Institutions conduct various programs to develop R and D facilities and Government related institutions offer training and upgrade skills of the technical staff.

As such, the increased demand has increased sales for Beverage, Food and Tobacco companies but it poses a great challenge with regards to inventory management of these companies in the country (Labour Market and Socio-economic Information Directorate (LMSID), Service Canada, Ontario). The rapid demand for Beverage, Food and Tobacco has augmented the inventory problem hence the need for effective and efficient inventory management. It is on this argument that this study aims to analyze the impact of inventory management on profitability of Beverage, Food and Tobacco sector companies listed in the Colombo Stock Exchange (CSE), Sri Lanka.

\section{Objectives of the Study}

The main objective of the study is to identify the impact of inventory management practices on Return on Asset as profitability of listed companies in beverage food and tobacco sector in Colombo Stock Exchange in Sri Lanka. 


\section{Research Questions}

RQ1: Do inventory management practices have an impact on profitability of listed companies in the beverage food and tobacco sector in Sri Lanka?

RQ2: What is the relationship between inventory management and profitability of listed companies in the beverage food and tobacco sector in Sri Lanka?

\section{Significance of the Study}

The study is to help investors beverage food and tobacco sector firms comprehend the impact of inventory on the profitability of beverage food and tobacco companies in Sri Lanka, and we hope that it helps the technical individuals to employ effective control techniques in order to improve on their sector firm's works for maximized the profit. Further, this study is aimed to add knowledge to the existing literature about inventory management and profitability of beverage food and tobacco sector companies in Sri Lanka.

\section{Review of literature}

Inventory is the stock purchased with the purpose of resale in order to gain a profit. It represents the largest cost to a manufacturing firm. For a manufacturing firm, inventory consists of between $20 \%$ and $30 \%$ of the total investment (Pedro Juan García-Teruel, Pedro Martínez-Solano, 2007).

Hopp and Spearman (2000) classify inventory into raw materials, work in progress, finished goods and spare parts. Raw materials are the stocks that have been purchased and will be used in the process of manufacture while work in progress represents partially finished goods.

Sekeroglu,and Altan (2014) say relationship between inventory management and profitability was analyzed with correlation and regression analysis. Accordingly, it is determined that there is a positive relationship between inventory management and profitability in eatables industry. According to the results, for the firms operating in the eatables industry, the more their inventories converted into Money, the more profitability ratios included in analysis. In other words, if the firms operating in this sector sustain their inventory management policies effectively, they increase their profits.

In Ghana, Prempeh (2015) studied the impact of efficient inventory management on the profitability of manufacturing firms by using raw material inventory management and profit as variables. Cross sectional data from the company annual reports of four manufacturing firms listed in Ghana Stock Exchange were analyzed using multiple regression techniques and Ordinary Least Squares (OLS). The study found a significantly positive strong relationship between raw material inventory management and profitability.

In 2012 Gupta and Gupta concluded in their one of the study as "the efficient management and effective control of inventories help in achieving better operational results and reducing investment in working capital. It has a significant influence on the profitability of a concern thus inventory management should be a part of the overall strategic business plan in every organization."

Salawati, Tinggi, andKadri, (2012) observed the impact of inventory management on performance. They empirically studied the relationship between inventory management and firm performance on a sample of financial data for 82 construction firms in Malaysia for a period 2006-2010. They employed regression and correlation technique to analyze their findings. Their finding was that inventory management is positively correlated with firm performance. Their study focused only on general performance of the firms using financial change as a performance indicator.

Adeleke, A and Aminu (2012) found as efficient and effective management of inventories also ensures business survival and maximization of profit which is the cardinal aim of every firm. More so, an efficient management of working capital through proper and timely inventory management ensures a balance between profitability and liquidity trade-offs.

In Greece, Koumanakos (2008) carryout a study to find the effect of inventory management on firm performance in manufacturing firms operating in three industrial sectors. For this purpose, period of $2000-2002$ considered and food textiles and chemicals sectors were used in this study. The study hypothesis of that lean inventory management leads to an improvement in financial performance of the firm was examined. The findings explored that the higher the level of inventories preserved (departing from lean operations) by a firm, the lower the rate of return. In Malaysia.

Considering all the literatures relating to this research it can see there are positive and negative relationships between profitability and inventory management. And most of the studies reviewed concentrated on conventional firm level variables such as inventory levels, demand and lead time. Sometimes the conclusions depend on the variables and population or sample which they used. However it is important to make sure that is there any relationship among these factors or not. In Sri Lankan context there are no significant researches relating to this topic. As well as most of those researches used different samples.

Furthermore according to the past studies, inventory convention period, current ratio, operating cycle and cash conversion cycle are used to measure effectiveness of inventory management for this study. In this study the 
Inventory management ratios are used to measure of Inventory management of the firms and therefore it is the independent variables.

\section{Methodology}

Data

This study mainly uses its source of data as financial statements of the selected companies' annual reports. Mainly the data from balance sheets and income statements were taken over 5 years from 2012 to 2016 . All this collected financial data are in terms of Sri Lankan currencies of Rupees. The purpose of getting 5 years period of data as balanced panel data set, and the study only considered the firms that are listed in CSE since 2011, hence that a period of 5 years data set can be obtained.

\section{Variables}

According to the objective of this study, inventory conversion period, current ratio, operating cycle and cash conversion cycle are used as measures of inventory management (as Independent variable) and the Return on Asset (ROA) used as a dependent variable to measure the profitability. The following hypothesis are developed based on the dependents and independents variable of this study.

\section{Hypothesis}

The hypothesized variables of inventory management and profitability were identified according to the review of the literatures from past scholarly works and as the reference of inventory management.

$\mathrm{H}_{1}$ : There is a relationship between inventory management practices and profitability of listed companies in beverage food and tobacco sector in Sri Lanka.

$\mathrm{H}_{2}$ : Inventory management has an impact on profitability of listed companies in beverage food and tobacco sector in Sri Lanka

\section{Model of the study}

The following OLS model has used to analyses the results

Where:

$$
\mathrm{ROA}_{\mathrm{it}}=\alpha+\beta_{1}(\mathrm{ICP})_{\mathrm{it}}+\beta_{2}(\mathrm{CR})_{\mathrm{it}}+\beta_{3}(\mathrm{OC})_{\mathrm{it}}+\beta_{4}(\mathrm{CCC})_{\mathrm{it}}+\mathrm{e}_{\mathrm{it}}
$$

$$
\begin{aligned}
& R O A_{\mathrm{it}}=\text { Return on Asset } \\
& I C P=\text { Inventory Conversion Period } \\
& \mathrm{CR}=\text { Current Ratio } \\
& \mathrm{OC}=\text { Operating cycle } \\
& \mathrm{CCC}=\text { Cash conversion cycle } \\
& \alpha=\text { the Y intercept } \\
& e_{\mathrm{it}}=\text { error }
\end{aligned}
$$

\section{Analysis}

Analysis was carried out in two methods of descriptive statistics method and inferential statistics method. Mainly data were collected by the primary survey, then sorted and analyzed by using a computerized data analysis package known as Stata12. Tables were used for purposes of presenting and analyzing the findings of the study. Pearson correlation and regressions were used to measure the relationships and strength between the studied variables.

\section{Results and discussions}

Table 1 explains the descriptive statistics of the dependent and independent variables used in the study. This critical descriptive statistics examination of the dependent and independent variables discloses several issue

Table 1: Descriptive statistics of dependent and independent variables (2012- 2016)

\begin{tabular}{llllll}
\hline Variable & Obs & Mean & Std. Dev. & Minimum & Maximum \\
\hline ICP & 100 & 63.6043 & 50.59704 & 10.12273 & 295.5786 \\
CR & 100 & 2.948528 & 5.391127 & .1167155 & 45.65175 \\
OC & 100 & 171.2038 & 108.8892 & 54.82003 & 443.4706 \\
CCC & 100 & 8.72313 & 228.4558 & -1465.523 & 1536.297 \\
ROA & 100 & 12.04539 & 13.04515 & -1.609611 & 60.26403 \\
\hline
\end{tabular}

Source: Results obtained from the data analysis using the statistical software package of Stata12.

$\mathbf{I C P}=$ inventory conversation period, $\mathbf{C R}=$ current ratio, $\mathbf{O C}=$ operating cycle, $\mathbf{C C C}=$ cash conversion cycle, $\mathbf{R O A}=$ return on asset.

This critical descriptive statistics examination of the dependent and explanatory variables discloses several issues. The study indicated that Profitability can be denoted by return on asset (ROA). The mean (average) return on asset (ROA) is $12.04 \%$ to the whole sample and standard deviation is 13.04 . This accounting measure (ROA) is used as profitability measure, which varies from $-1.6 \%$ to $60.26 \%$ with mean ratio of $12.04 \%$, and explains that beverage food and tobacco sector firms have an average accounting performance. The difference in return on asset ranged from profitability of $60.26 \%$ (maximum value) for some firms to a loss of $1.6 \%$ (minimum value) for other 
some firms. This explores a great disparity among the firms in their profitability.

Among the measures of inventory management, operating cycle has a highest average ratio of 171.2 this means that an average number of days a company takes in realizing its inventories in cash about 171 days in beverage food and tobacco sector companies in CSE. Current Ratio (CR) has a lowest average ratio of 2.95 that's means an average short-term solvency position is 2.95 times in beverage food and tobacco sector companies in CSE.

Further the other measures of inventory management is inventory conversation period (ICP) and cash conversion Cycle (CCC), they have an average ratio of 63.60 and 8.72 respectively.

Finally, when looking through the standard deviation (SD) measures which is helpful to know the variables' level of variation from their mean value. Here in this study explores that the most volatile variable among the examined variables is cash conversion cycle (CCC) with a S.D of 228.46 followed by operating cycle (OC) with a S.D of 108.89 then inventory conversation period (ICP) with 50.60. Whereas the least volatile (most stable) variable is current ratio (CR) with a S.D of 5.39 followed return on asset (ROA) with 13.04.

\section{Correlation Matrix}

The correlation matrix of the independent and dependent variables is presented in Table 2 below. The results reveal that the return on asset has a positive relationship with the inventory management measures of inventory conversation period, which is $33.11 \%$ significant at $05 \%$ significant level. This is not consistent with the analysis that the lower the number of days the inventory is held in a firm before its turnover, the more the assets are utilized in the firm increasing profitability, whereas a negative relationship with cash conversion cycle, which is $-20.36 \%$ significant at $05 \%$ significant level( this result strengthens the finding of Takon, 2013 and Lazaridis and Tryfonidis, 2006). In case of other two inventory management measures of operating cycle and Current ratio are also have positive relationship but low degree of strength with $00.68 \%$ and $11.84 \%$ respectively and that is not significant at $05 \%$ significant level. So, we can say only inventory conversation period has a positive influence with the profitability measures of return on asset of beverage food and tobacco Companies listed in Colombo stock exchange of Sri Lanka.

This finding revel that the Sri Lankan listed firms of beverage and food sector companies express a positive association of inventory conversation period and negative association of cash conversion cycle with profitability measure of return on asset. It implies that Sri Lankan listed firms of beverage and food sector companies' (they are small compare to firms in developed countries) inventory conversion period only has a significant positive influence and cash conversion cycle has a negative significant influence on return on asset and the null hypothesis 1 is rejected in-case of inventory converstion period and cash conversion cycle.

This result is consistent with Shin and Soenen (1998); Lyroudi and Lazaridis (2000); Abuzayed (2012); Abuzayed (2012) and Takon (2013).

Table 2: Correlation Matrix of the Variables (2012 -2016) and VIF

\begin{tabular}{lcccccc}
\hline & ICP & CR & OC & CCC & ROA & VIF \\
\hline ICP & 1.0000 & & & & & 2.29 \\
CR & $0.2798^{*}$ & 1.0000 & & & 2.06 \\
OC & $0.6319^{*}$ & -0.1438 & 1.0000 & & 1.38 \\
CCC & $-0.3266^{*}$ & 0.1372 & $-0.3451^{*}$ & 1.0000 & & 1.21 \\
ROA & $0.3311^{*}$ & 0.0068 & 0.1184 & $-0.2036^{*}$ & 1.0000 & \\
\hline
\end{tabular}

Note: $\mathrm{ICP}=$ Inventory conversion period; $\mathrm{CR}=\mathrm{Current}$ ratio; $\mathrm{OC}=$ Operating cycle; $\mathrm{CCC}=$ cash conversion cycle; $\mathrm{ROA}=$ Return on asset, $*$-Significant at $05 \%$ level

Source: Results obtained from the data analysis using the statistical software package of StataSE12.

Normally when we are doing the regression analysis, that the statistical problem of multicollinearity issue should considered among the independent variables.

As per the recommendation of Gujarati (2003) Variance inflation factor (VIF) can be used to diagnostics of multicollinearity issues among the explanatory variables. VIF measures express that how much that the estimated regression coefficients variance is inflated due to the correlations among the predictors in the model.

The VIF values among the independent variables of Sri Lankan beverage food and tobacco sector firms are examined and tabulated with Table 2 and its appear that none of the VIF value indicates above the value of 3 (cutoff value is 10) this shows that multicollinearity problem does not exist among the explanatory variables used in this study.

\section{Regression analysis}

Regression analysis evaluates the relationship and its strength between dependent and independent variables. Multiple regression analysis performed and given the results below in the Table 3. 
Table 3: Effect of inventory management measures on return on Asset

\begin{tabular}{lcccc}
\hline ROA & Coefficient & SE & $\boldsymbol{t}$-statistic & Prob. \\
\hline ICP & .1299423 & .0367246 & 3.54 & 0.001 \\
CR & -.3794811 & .2681161 & -1.42 & 0.160 \\
OC & -.0310935 & .016206 & -1.92 & 0.058 \\
CCC & -.006112 & .0059066 & -1.03 & 0.303 \\
Constant & 10.27605 & 2.571659 & 4.00 & 0.000 \\
\hline
\end{tabular}

Note: $\mathrm{R}^{2}=0.1568 ;$ Adjusted $\mathrm{R}^{2}=0.1213 ; \mathrm{F}(4,95)=4.42 ;$ Prob $>\mathrm{F}=0.0026$

$\mathrm{ROA}=$ Return on asset; $\mathrm{ICP}=$ Inventory conversation period; $\mathrm{OC}=$ operating cycle; $\mathrm{CR}=$ current ratio; $\mathrm{CCC}=$ cash conversion cycle.

Source: Results obtained from the data analysis using the statistical software package of StataSE12.

As per the results on Table 3, model has a $\mathrm{R}^{2}$ value of 0.1568 that indicates the explanatory power of the dependent variables to the independent variables. It means $15.68 \%$ of the variation in return on asset of the beverage food and tobacco sector companies is explained through the selected independent variables; inventory management which is represent the inventory conversation period, current ratio, operating cycle and cash conversion cycle; whereas $84.32 \%$ is explained by other variables outside to this model.

The adjusted $\mathrm{R}^{2}$ represent when another one variable is added to the model, how far it will explain the dependent variable. Adjusted $\mathrm{R}^{2}$ is 0.1213 in this model and when added to new variable in this model, it will explain $12.13 \%$ of the return on asset of the companies. This indicated that our model is a predictor, which indicates that there is a positive relationship between the dependent variable (ROA) and the set of independent variables which are used in this model.

According to these observations of dependent variable, model values concludes that, this is a statistically good fitted model. Because to this model's $\mathrm{F}$ value is 0.0026 which indicates that model is significant at $5 \%$ confidence level. So the null hypothesis 2 is rejected.

$$
\mathrm{ROA}=\mathbf{1 0 . 2 8}+\mathbf{0 . 1 3 I C P}-\mathbf{0 . 3 8 C R}-\mathbf{0 . 0 3 1 0 C}-\mathbf{0 . 0 0 6 C C C}
$$

\section{Conclusions}

A notable dissimilarity between the inventory management influences on profitability measure of Sri Lankan firms and developed countries' firms is that Sri Lankan firms most probably inventory conversation period have considerable influence on its profitability. This situation exposes that, in the Sri Lankan firm's inventory conversation period is higher.

According to the findings of operating cycle, Sri Lankan firms' operating cycle has a negative influence on return on asset. This situation exposes that, in the Sri Lankan firm's operating cycle is considerable higher.

Whereas findings of cash conversion cycle, it has a negative influence on return on asset. This situation exposes that, in the Sri Lankan firm's cash conversion cycle is considerable lower. And findings of current ratio, its influence on return on asset is insignificant.

The findings of this empirical research study propose that a number of insights from western developed capital structure theories can be convenient to Sri Lanka, further that the certain firm's specific factors which are relevant for describing inventory management and firm's profitability in Western countries are also relevance to Sri Lanka.

\section{Recommendations}

Corresponding to the findings of this empirical study, the following appropriate recommendations are stated: Sri Lankan beverage food and tobacco sector listed firms should try to have high inventory conversation period, it can be help to make more profit (ROA). Sri Lankan beverage food and tobacco sector listed firms should try to have low degree of cash conversion cycle; it can be help to make more profit (ROA).

\section{Contribution to knowledge}

This research study contributes to the existing literature through examining the inventory management measures which influence on return on asset of Sri Lankan beverage food and tobacco sector listed firms from the view of that firm's inventory management measures. This study helps to understand the impact of inventory management measures with Sri Lankan beverage food and tobacco sector return on asset and how they affect their performance. This study findings can be helpful to board of directors and finance managers of Sri Lankan beverage food and tobacco sector firms as an output of this research study can serve as a useful database and resource material in the area of inventory management and profitability related decision makings.

\section{Reference}

Abuzayed, B. (2012). Working Capital Management And Firms' Performance In Emerging Markets: The Case Of Jordan. International Journal of Managerial Finance, 8(2), 155-179.

Adeleke, A and Aminu S. A. (2012) “The Determinants of Customer Loyalty in Nigeria's GSM Market”; 
International Journal of Business and Social Science"; Vol 3 (14)

Balakrishnan, R., T. J. Linsmeier, and M. Venkatachalam. (1996). Financial benefits from JIT adoption: Effects of customer concentration and cost structure. The Accounting Review 71: 183-205.

Boute, R., Lambrecht, M. and Lambrechts, O. (2004). Did Just-In-Time management effectively decrease inventory ratios in Belgium? Tijdschrift voor Economie en Management, Vol. XLIX (3), pp. 441-456.

Boute, R., Lambrecht, M., Lambrechts, O. and Sterckx, P. (2006), "An analysis of inventory turnover in the Belgian manufacturing industry, wholesale and retail and the financial impact of inventory reduction", in Proceedings of the 14th 2006 Euroma Conference, Strathclyde, June. [Google Scholar]

Chen, H., Frank, M. Z., and Wu, Q. W. (2005). What actual happened to the inventories of American companies between 1981 and 2000? Management sciences, 51, 1051-1031

Deloof, M. (2003). Does working capital management affect profitability of Belgian firms? Journal of Business Finance and Accounting, 30(3/4), 573-588.

Dudley, L. and Lasserre, P. (1989), "Information as a Substitute for Inventories," European Economic Review, Vol. 31: 1-21.

Gujarati, D. N. (2003) Basic Econometrics (fifth edition),McGraw-Hill.

Gupta, S. \& Gupta, S. (2012). Effective Inventory Visibility- Its Impact on Profitability. International Indexed \& Referred Research Journal, 4 (39), 59-60

Hopp, W. J., and Spearman, M. L. (2000). Factory Physics: Foundations of Manufacturing Management, Irwin/McGraw-Hill, Boston, MA.

http://www. Supplychainmusings.com/2008/05/optimizationtransportation-versus.html

Huson, M., and Nanda, D. (1995). The impact of just-in-time manufacturing on firm performance in the U.S. Journal of Operations Management, 9(1), 5-14.

Koh et al., (2007) Koh, S.C. L, Demirbag, M., Bayraktar, E., Tatoglu, E., and Zaim, S. (2007). The impact of supply chain management practices on performance of SMEs. Industrial Management and Data Systems, 107(1), 103-124.

Koumanakos, D. P. (2008) "The effect of inventory management on firm performance", International Journal of Productivity and Performance Management, Vol. 57 Issue: 5, pp.355-369, https://doi.org/10.1108/17410400810881827.

Lazaridis I, Tryfonidis D, (2006). Relationship between working capital management and profitability of listed companies in the Athens stock exchange. Journal of Financial Management and Analysis, 19: 26-25.

Lyroudi, K., \& Lazaridis, Y. (2000). The Cash Conversion Cycle and Liquidity Analysis of the Food Industry in Greecell. EFMA 2000 Athens. [Online] Available: http://ssrn.com/paper=236175.

Milgrom, P., and J. Roberts (1988): “An Economic Approach to Influence Activities in Organization,” American Journal of Sociology 94, 154-179.

Pedro Juan García-Teruel, Pedro Martínez-Solano, (2007) "Effects of working capital management on SME profitability", International Journal of Managerial Finance, Vol. 3 Issue: 2, pp.164-177, https://doi.org/10.1108/17439130710738718.

Prempeh, K.B. (2015). The impact of efficient inventory management on profitability: evidence from selected manufacturing firms in Ghana. MPRA Paper No. 67889. Available online at https://mpra.ub.unimuenchen.de/67889/.

Rotemberg, J.J. and Saloner, G. (1989), The Cyclical Behavior of Strategic Inventories", Quarte r ly Jou rn a 1 of Econom ics, Vol. 104, pp. 73 - 97.

Salawati, S., Tinggi, M., and Kadri, N. (2012). inventory management in malasyian construcion firms: impact on performance. SIU Journal management, 2, 59-60.

Schreibfeder, J. (2004) Your Ideal Inventory. Effective Inventory Management Inc. South Denton htrtp://www,effectiiveinventory.com/article.htm

Sekeroglu G, Altan M (2014) International Scholarly and Scientific Research \& Innovation 8(6) 2014 Pp. 1703

Shah, R. and H. Shin. (2007). Relationships among information technology, inventory and profitability: An investigation of level invariance using sector level data, Journal of Operation Management, 15, pp 768-84.

Shin H. and L. Soenen (1998) Efficiency of Working Capital and Corporate Profitability, Journal Financial Practice and Education, Vol. 8, 37-45.

Sitienei, E. and Memba, F. (2016) The Effect of Inventory Management on Profitability of Cement Manufacturing Companies in Kenya: A Case Study of Listed Cement Manufacturing Companies in Kenya. International Journal of Management and Commerce Innovations, 3(2), 111-119.

Takon, S. (2013). Does Cash Conversion Cycle Have Impact on Return on Assets of Nigerian Firms? Research Journal of Finance and Accounting. Vol.4, No.14, 2013, pp. 34-42.

Temeng, V. A., Eshun, P. A., \& Essey, P. R. K. (2010). Application of inventory management principles to explosive products manufacturing and supply-a case study. International research journal of finance and economics, 38, 198-209. 